\title{
Pós-graduação e produção de conhecimentos em Fisioterapia na América Latina: qual é o papel do Brasil?
}

Postgraduation and production of knowledge in physiotherapy in Latin America: what is the role of Brazil?

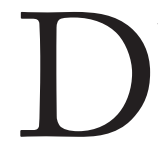
urante muitos anos, os fisioterapeutas atuaram com base em livros de reabilitação importados cuja característica marcante eram as "receitas" prontas, que dispensavam a necessidade de pensar para tomar decisões. A importação de técnicas norte-americanas e europeias era notória nas décadas de 1960 e 1970, e ainda hoje são utilizadas. Essas técnicas ou métodos provinham da experiência e tinham frágil fundamentação científica.

A mudança do rumo da fisioterapia no Brasil começou na década de 1980, quando alguns fisioterapeutas brasileiros, em especial os envolvidos com ensino, começaram a procurar alternativas para fazer mestrado e doutorado e buscaram áreas correlatas para realizá-los: Fisiologia, Medicina, Morfologia, Engenharia, Farmácia, Psicologia etc. Foram muitas as dificuldades, pois poucos acreditavam na capacidade dos fisioterapeutas para se inserirem em áreas tão diferentes. Ao final, conseguimos capacitar um pequeno número de doutores, mas permanecia a pergunta: como transferir os conhecimentos de outras áreas para a produção de conhecimentos na Fisioterapia?

Em 1997 veio a resposta, com o primeiro programa de pós-graduação em Fisioterapia, e hoje, após 15 anos, chegamos aos 14 programas.

Hoje nos deparamos com situação semelhante nos demais países da América Latina que integram a Confederação Latino-Americana de Fisioterapia e Kinesiologia (CLAFK): poucos fisioterapeutas titulados, programas específicos de pós-graduação raros, dificuldade de migração a outros países para obter os títulos e a produção de conhecimentos, que avança muito lentamente.

Um estudo feito recentemente mostra em números a realidade das publicações de Fisioterapia na América Latina: o Brasil é responsável por 70,1\%; em seguida vem o Chile, com 13,4\%; Colômbia, 6\%; Argentina e Venezuela, 3, 4\%; e Cuba e Peru, $1 \%$.

A sugestão é levar aos países integrantes da CLAFK a experiência brasileira: investir na formação de mestres e doutores em outras áreas da saúde até a criação dos primeiros cursos de pós-graduação em Fisioterapia; estimular a produção de conhecimentos, que pode começar pela graduação por meio da iniciação cientifica e incentivar as publicações cientificas em nível nacional e internacional.

Este pode ser o caminho para dar maior visibilidade e credibilidade à Fisioterapia em toda a América Latina e, consequentemente, junto à World Confederation for Physical Therapy (WCPT).

Amélia Pasqual Marques EDITORA 